\title{
THE RESPONSE OF TENOCYTES TO COMMERCIAL SCAFFOLDS USED FOR ROTATOR CUFF REPAIR
}

\author{
R.D.J. Smith ${ }^{1,2}$, A. Carr ${ }^{1,2,}$, S.G. Dakin ${ }^{1,2}$, S.J.B. Snelling ${ }^{1,2}$, C. Yapp ${ }^{3}$ and O. Hakimi ${ }^{1,2}$ \\ ${ }^{1}$ Nuffield Department of Orthopaedics, Rheumatology and Musculoskeletal Sciences, University of Oxford, \\ Old Road, Oxford, OX3 7LD, UK. \\ ${ }^{2}$ The Botnar Research Centre, Oxford University Institute of Musculoskeletal Sciences, \\ NIHR Oxford Biomedical Research Unit, Oxford, OX3 7LD, UK. \\ ${ }^{3}$ Target Discovery Institute, Nuffield Department of Medicine, University of Oxford, Old Road Campus, \\ Oxford, OX3 7FZ, UK.
}

\begin{abstract}
Surgical repairs of rotator cuff tears have high re-tear rates and many scaffolds have been developed to augment the repair. Understanding the interaction between patients' cells and scaffolds is important for improving scaffold performance and tendon healing.

In this in vitro study, we investigated the response of patient-derived tenocytes to eight commercial scaffolds. Tested scaffolds included X-Repair, Poly-Tape, LARS Ligament, BioFiber (synthetic scaffolds), BioFiber-CM (biosynthetic scaffold), GraftJacket, Permacol, and Conexa (biological scaffolds). Cell attachment, proliferation, gene expression, and morphology were assessed.

After one day, more cells attached to synthetic scaffolds with dense, fine and aligned fibres (X-Repair and PolyTape). Despite low initial cell attachment, the human dermal scaffold (GraftJacket) promoted the greatest proliferation of cells over 13 days. Expression of collagen types I and III were upregulated in cells grown on noncross-linked porcine dermis (Conexa). Interestingly, the ratio of collagen I to collagen III mRNA was lower on all dermal scaffolds compared to synthetic and biosynthetic scaffolds.

These findings demonstrate significant differences in the response of patient-derived tendon cells to scaffolds that are routinely used for rotator cuff surgery. Synthetic scaffolds promoted increased cell adhesion and a tendonlike cellular phenotype, while biological scaffolds promoted cell proliferation and expression of collagen genes. However, no single scaffold was superior. Our results may help understand the way that patients' cells interact with scaffolds and guide the development of new scaffolds in the future.
\end{abstract}

Keywords: Rotator cuff tears, scaffolds, materials, tenocytes, polymers, extracellular matrix, in vitro.

\footnotetext{
* Address for correspondence:

Prof. Andrew Carr

The Botnar Research Centre,

University of Oxford, Nuffield Orthopaedic Centre, Windmill Road, Oxford, OX3 7LD, UK
}

Telephone number: +44 1865227374

Email: andrew.carr@ndorms.ox.ac.uk

\section{Introduction}

Shoulder pain is the third commonest cause of musculoskeletal pain in society, and $1 \%$ of all adults see their doctor for new shoulder pain every year (Urwin et al., 1998). In the UK, $14 \%$ of the population report shoulder problems and rotator cuff problems are the most common cause of pain (Urwin et al., 1998; Chaudhury et al., 2010). Between $5 \%$ (Neer, 1983) and $39 \%$ (DePalma et al., 1949) of the general population have rotator cuff tears, and prevalence is expected to increase as the population ages (Yamamoto et al., 2010). Large and massive rotator cuff tears (tear size $\geq 3 \mathrm{~cm}$ ) (Post et al., 1983) do not heal spontaneously and often require surgical intervention (Cornwell et al., 2009). Approximately 10,000 rotator cuff surgeries are performed in the UK every year (Judge et al., 2014), in addition to the 75,000-300,000 surgeries performed annually in the United States (Aurora et al., 2007; Vitale et al., 2007; Marx et al., 2009). However, many surgical repairs fail, with re-tear rates reported between $11 \%$ (Lafosse et al., 2007) and $94 \%$ (Galatz et al., 2004). Patients who re-tear have reduced functional outcome (Sugaya et al., 2007; Gerber et al., 2000) and fewer treatment options available. In light of this, scaffolds have become a popular method of stabilising surgical repairs.

A variety of scaffolds are now commercially available for the augmentation of rotator cuff reattachments (Table 1). These can be biological, synthetic or a combination thereof. Biological scaffolds are allografts or xenografts derived from decellularised mammalian tissue. Biological scaffolds are expected to retain biological (Bissell and Aggeler, 1987; Voytik-Harbin et al., 1997) and structural (Bissell and Barcellos-Hoff, 1987; Badylak, 2007) cues that instruct cell migration (Reing et al., 2009), proliferation (Ling et al., 1990) and phenotype (Gong et al., 2008) to promote repair (Derwin et al., 2010; Zantop et al., 2006). Popular biological scaffolds include GraftJacket (Wright Medical, Arlington, TN, USA), Permacol (Tissue Science Laboratories, Covington, GA, USA) - also marketed as Zimmer Collagen Repair Patch (Zimmer, Warsaw, IN, USA), TissueMend (Stryker Orthopedics, Mahwah, NJ, USA) and Conexa (Tornier, Inc., Edina, MN, USA).

Synthetic scaffolds are mostly made of polyester polymers, and examples include X-Repair (Synthasome, San Diego, CA, USA), Poly-Tape (Neoligaments, Leeds, UK), BioFiber (Tornier, Inc., Edina, MN, USA) and LARS Ligament (LARS, Arc-sur-Tille, Burgundy, France). 
Table 1. Commercial scaffold information. Scaffold name, manufacturer, industrial supplier, source material, scaffold type, cross-linked, and terminally sterilised.

\begin{tabular}{|l|c|c|c|c|c|c|}
\hline \multicolumn{1}{|c|}{$\begin{array}{c}\text { Scaffold } \\
\text { Name }\end{array}$} & Manufacturer & Sndustrial Supplier & Source & Scaffold Type & $\begin{array}{c}\text { Cross- } \\
\text { Linked }\end{array}$ & $\begin{array}{c}\text { Terminally } \\
\text { Sterilised }\end{array}$ \\
\hline X-Repair & $\begin{array}{c}\text { Synthasome } \\
\text { (San Diego, CA, USA) }\end{array}$ & $\begin{array}{c}\text { Synthasome } \\
\text { (San Diego, CA, USA) }\end{array}$ & Poly- L-lactic-acid & Synthetic & $\mathrm{N}$ & $\mathrm{Y}$ \\
\hline $\begin{array}{l}\text { LARS } \\
\text { Ligament }\end{array}$ & $\begin{array}{c}\text { LARS } \\
\text { (Arc-sur-Tille, } \\
\text { Burgundy, France) }\end{array}$ & $\begin{array}{c}\text { LARS } \\
\text { (Arc-sur-Tille, } \\
\text { Burgundy, France) }\end{array}$ & $\begin{array}{c}\text { Polyethylene } \\
\text { Terephthalate }\end{array}$ & Synthetic & $\mathrm{N}$ & $\mathrm{Y}$ \\
\hline Poly-Tape & $\begin{array}{c}\text { Xiros plc, Neoligaments } \\
\text { (Leeds, UK) }\end{array}$ & $\begin{array}{c}\text { Neoligaments } \\
\text { (Leeds, UK) }\end{array}$ & $\begin{array}{c}\text { Polyethylene } \\
\text { Terephthalate }\end{array}$ & Synthetic & $\mathrm{N}$ & $\mathrm{Y}$ \\
\hline BioFiber & $\begin{array}{c}\text { Tornier } \\
\text { (Edina, MN, USA) }\end{array}$ & $\begin{array}{c}\text { Tornier } \\
\text { (Edina, MN, USA) }\end{array}$ & Poly(4-hydroxybutyrate) & Synthetic & $\mathrm{N}$ & $\mathrm{Y}$ \\
\hline $\begin{array}{l}\text { BioFiber- } \\
\text { CMM }\end{array}$ & $\begin{array}{c}\text { Tornier } \\
\text { (Edina, MN, USA) }\end{array}$ & $\begin{array}{c}\text { Tornier } \\
\text { (Edina, MN, USA) }\end{array}$ & $\begin{array}{c}\text { Poly(4-hydroxybutyrate) } \\
+ \text { Bovine Collagen }\end{array}$ & Biosynthetic & $\mathrm{N}$ & $\mathrm{Y}$ \\
\hline GraftJacket & $\begin{array}{c}\text { LifeCell } \\
\text { (Branchburg, NJ, USA) }\end{array}$ & $\begin{array}{c}\text { Wright Medical } \\
\text { Technology } \\
\text { (Arlington, TN, USA) }\end{array}$ & Human Dermis & Biological & $\mathrm{N}$ & $\mathrm{N}$ \\
\hline Permacol & $\begin{array}{c}\text { Tissue Science Laboratories } \\
\text { (Aldershot, Hampshire, UK) }\end{array}$ & $\begin{array}{c}\text { Zimmer } \\
\text { (Warsaw, IN, USA) }\end{array}$ & Porcine Dermis & Biological & $\mathrm{Y}$ & $\mathrm{Y}$ \\
\hline Conexa & $\begin{array}{c}\text { Tornier } \\
\text { (Edina, MN) }\end{array}$ & $\begin{array}{c}\text { Tornier } \\
\text { (Edina, MN) }\end{array}$ & Porcine Dermis & Biological & $\mathrm{N}$ & $\mathrm{Y}$ \\
\hline
\end{tabular}

Synthetic scaffolds permit the customisation of specific mechanical (Zhang et al., 2012) and chemical properties (Chen et al., 2009) that can stabilise the repair (Derwin et al., 2009). Recently, biosynthetic scaffolds have emerged, an example of which is BioFiber-CM (Tornier, Inc., Edina, MN, USA) which is a woven synthetic scaffold coated with bovine collagen.

Pre-clinical studies have reported favourable results using both biological (Cook et al., 2008; Shea et al., 2010) and synthetic scaffolds (Derwin et al., 2009; McCarron et al., 2010). However, results have not always been replicated in humans and several clinical studies have reported adverse reactions (Malcarney et al., 2005; Phipatanakul and Petersen, 2009) and increased failure rates (Iannotti et al., 2006; Sclamberg et al., 2004) following scaffold use. This discrepancy illustrates the inadequacy of existing pre-clinical models to replicate human pathologies. Many studies artificially lacerate tendons in healthy animals (Dejardin et al., 2001; Zalavras et al., 2006) or use healthy tendon cells in vitro (Cook et al., 2008; Shea et al., 2010). Previous studies have demonstrated differences in tenocytes derived from healthy tissue compared to those derived from diseased tissue: specifically, differences in the expression of collagen (Maffulli et al., 2000), inflammatory mediators (Dakin et al., 2015) and apoptotic markers (Millar et al., 2012) have been reported. Many previous studies that have investigated the response of tenocytes to biomaterials have overlooked this distinction.

Thus, the precise manner by which patients' cells interact with these scaffolds remains unclear. In addition, the large number of scaffolds and variety of experimental paradigms used to test them makes it difficult to compare different scaffolds.

Therefore, the purpose of this in vitro study was to compare the response of tenocytes from rotator cuff tear patients to 8 commercially available scaffolds in terms of initial cell attachment, cell proliferation, final cell number, gene expression, and cell morphology. We hypothesised that there would be significant differences in the parameters assessed between the different scaffolds tested.

\section{Materials and Methods}

\section{Scaffold selection}

Scaffolds were selected based on presence in the literature and commercial availability (Table 1). Biological, biosynthetic, and synthetic scaffolds were selected to represent a cross-section of the spectrum of available scaffolds.

\section{Human tendon tissue acquisition}

Biopsies of torn supraspinatus tendons were taken from three male patients aged 40-65 undergoing surgical repair for large or massive rotator cuff tears. Tendon biopsies were collected with informed donor consent under ethics from the Oxford Musculoskeletal Biobank (09/H0606/11) in compliance with the National and Institutional ethical requirements. During surgery, biopsies were immediately transferred into sterile tubes containing DMEM F12 media (Lonza, Slough, UK) and were then used for cell isolation.

\section{Tenocyte cell isolation and culture}

Tenocytes were extracted by cutting the tissue biopsies into small pieces, approximately $2 \times 2 \mathrm{~mm}$ square and transferred to 6-well plates (Corning Inc., Corning, NY, USA). Cells were cultured in supplemented media: DMEM F12 media (Lonza, Slough, UK), $10 \%$ foetal bovine serum (Labtech, Uckfield, UK), and $1 \%$ PenicillinStreptomycin (Thermo Fisher Scientific, Waltham, MA, USA). Supplemented media was replaced every $3 \mathrm{~d}$. Once cells had reached confluence, they were scraped and transferred to $10 \mathrm{~cm}$ Petri dishes (Greiner, Frickenhausen, Germany). Cells from each patient were used separately for each experiment and were used in passage 3 to avoid phenotypic drift experienced at higher passages (Yao et al., 2006).

\section{Scaffold preparation and tissue culture}

Scaffolds were prepared according to manufacturer's instructions, then conditioned in supplemented media for $24 \mathrm{~h}$ prior to cell seeding in static culture. Cells were 
seeded at a density of 100,000 cells $/ \mathrm{cm}^{2}$ for all experiments, except for cell morphology, where cells were seeded a density of 10,000 cells $/ \mathrm{cm}^{2}$. After cell seeding, all scaffolds were transferred to new well plates. Scaffolds were then transferred to new well plates with fresh media every $3 \mathrm{~d}$ such that only cells attached to the scaffolds were accounted for. Unless stated otherwise, tissue culture plastic (TCP) was used as a positive control and unseeded scaffolds were used as negative controls.

\section{Environmental scanning electron microscopy (ESEM)}

A $0.25 \mathrm{~cm}^{2}$ piece of each scaffold was rinsed in phosphate buffered saline (PBS, Sigma-Aldrich, St. Louis, MO, USA) for $10 \mathrm{~min}$ then fixed in $2.5 \%$ glutaraldehyde (SigmaAldrich, St. Louis, MO, USA) for $24 \mathrm{~h}$. Scaffolds were rinsed in deionised water before undergoing a graded ethanol series (Sigma-Aldrich) (40, 70, 90, 95 and $100 \%$ each for $10 \mathrm{~min}$ ). Next, $100 \mu \mathrm{L}$ of hexamethyldisilazane (Alfa Aesar, Ward Hill, MA, USA) was added to each scaffold for $24 \mathrm{~h}$. Scaffolds were gold coated using a SC7620 Mini Sputter Coater System (Quorum Technologies Ltd, Laughton, UK) and images were taken at $50 \times$ magnification using an Evo LS15 Variable Pressure Scanning Electron Microscope (Carl Zeiss AG, Oberkochen, Germany). The diameter of individual fibres was determined using Image J (National Institute of Health, Bethesda, MD, USA).

\section{Initial cell attachment and final cell number}

Six $1 \mathrm{~cm}^{2}$ samples of each scaffold were seeded with 100,000 cells in a 24-well plate (Corning Inc., Corning, NY, USA). Three scaffolds were processed on day 1 to measure initial cell attachment. On day 13, the remaining scaffolds were processed to assess the final cell number.

For processing, scaffolds were rinsed twice in PBS (Sigma-Aldrich) then suspended in $350 \mu \mathrm{L}$ of $0.2 \%$ Nonidet P40 (Fluka Biochemika, Buchs, Switzerland). Scaffolds were freeze-thawed three times and sonicated twice for $10 \mathrm{~s}$ using an ultrasonic cell disruptor (Misonix, Farmingdale, NY, USA). The double stranded DNA (dsDNA) content of each well was quantified using the Quant-iT PicoGreen assay (Invitrogen, Paisley, UK) according to manufacturer's instructions.

\section{Cell proliferation}

Six $1 \mathrm{~cm}^{2}$ samples of each scaffold were seeded with 100,000 cells and cultured in 24-well plates (Corning). A calibration curve was generated by seeding cells at the following densities in a 48 -well plate (Corning): $5 \times 10^{3} / \mathrm{cm}^{2}, 1 \times 10^{4} / \mathrm{cm}^{2}, 5 \times 10^{4} / \mathrm{cm}^{2}$ and $1 \times 10^{5} / \mathrm{cm}^{2}$. This was used to approximate cell number throughout the experiment. Cell proliferation on scaffolds was quantified using AlamarBlue Assay, which has been validated previously (Ahmed et al., 1994; Voytik-Harbin et al., 1998). Every three days, scaffolds were incubated in $5 \%$ AlamarBlue (Invitrogen) in supplemented media for $2 \mathrm{~h}$. Fluorescence was measured at $485 \mathrm{~nm}$ excitation and $520 \mathrm{~nm}$ emission using a FLUOstar optima microplate reader (BMG Labtech, Ortenberg, Germany).

\section{Gene expression}

Three $1 \mathrm{~cm}^{2}$ samples of each scaffold were seeded with 100,000 cells in a 24-well plate (Corning). After $13 \mathrm{~d}$, scaffolds were rinsed in PBS (Sigma-Aldrich) then fixed in $1 \mathrm{~mL}$ TRIzol (Invitrogen). The mRNA was extracted using the Direct-zol RNA miniprep kit (Zymo Research, Irvine, CA, USA) and mRNA quality was checked using a Nanodrop ND1000 (Nanodrop Technologies, Willington, DE, USA) and all samples had 260/280 value greater than 1.6. The mRNA was then converted to cDNA using a High Capacity cDNA Reverse Transcription Kit (Applied Biosystems, Waltham, MA, USA). Final cDNA was diluted to $5 \mathrm{ng} / \mu \mathrm{L}$ and $1 \mu \mathrm{L}$ was used in a $10 \mu \mathrm{L}$ reaction with Fast SYBR Master Mix (Applied Biosystems) according to manufacturer's protocol. The RT-qPCR reaction was performed using a ViiA7 real-time PCR machine (Applied Biosystems). Glyceraldehyde 3-phosphate dehydrogenase $(G A P D H)$ and TATA-binding protein $(T B P)$ were used as endogenous reference genes and gene expression was calculated using the comparative CT method (Schmittgen and Livak, 2008). QuantiTect primers for COL1A1, COL3A1, GAPDH, COL2A1, COL6A1, TNC, DCN, $S C X-B, T N M D, V C A N, A C A N$ and $T B P$ were used in the RT-qPCR reaction (Qiagen, Hilden, Germany).

\section{Cell morphology}

Six $0.5 \times 0.5 \mathrm{~cm}$ samples of each scaffold were seeded with $2.5 \times 10^{4}$ cells in a 48 -well plate (Corning). Three samples of each scaffold were fixed in $10 \%$ formalin (Fischer Scientific, Loughborough, UK) on days 1 and 13. Samples were incubated in $1 \mathrm{~mL} 0.5 \%$ Triton-X (Thermo Fisher Scientific, Waltham, MA, USA) for $10 \mathrm{~min}$, then rinsed in PBS (Sigma-Aldrich). A $100 \mathrm{nM}$ solution of acti-stain 488 phalloidin (Cytoskeleton Inc., Denver, CO, USA) and 4', 6-diamidino-2-phenylindole (DAPI) (Thermo Fisher Scientific, Waltham, MA, USA) was generated in PBS (Sigma-Aldrich) and $500 \mu \mathrm{L}$ of the solution was added to each scaffold and incubated for $2 \mathrm{~h}$ in the dark at $4{ }^{\circ} \mathrm{C}$. Scaffolds were rinsed in PBS (Sigma-Aldrich) and images were captured at $40 \times$ magnification using a Zeiss LSM710 confocal microscope (Carl Zeiss AG, Oberkochen, Germany).

\section{Statistical analysis}

A Kolomogorov-Smirnov test was performed for each assay to determine normality. Technical replicates were included for assays where the number of biological replicates was not sufficient to determine normality. Unless otherwise stated, a one-way ANOVA was performed and a Tukey post-hoc test was completed to compare all scaffolds tested. To compare the ratios of collagen I to collagen III expression between dermal and synthetic/biosynthetic scaffolds, a two-tailed unpaired $t$-test was performed. Statistical analysis was performed using GraphPad PRISM (GraphPad Software Inc., La Jolla, CA, USA). Statistical significance was considered at $* p \leq 0.05, * * p \leq 0.01$, $* * * p \leq 0.001$, and $* * * * p \leq 0.0001$. Statistical significance represents the minimum statistical differences between the designated scaffold and every other scaffold. If more than one scaffold is significantly different from the other 

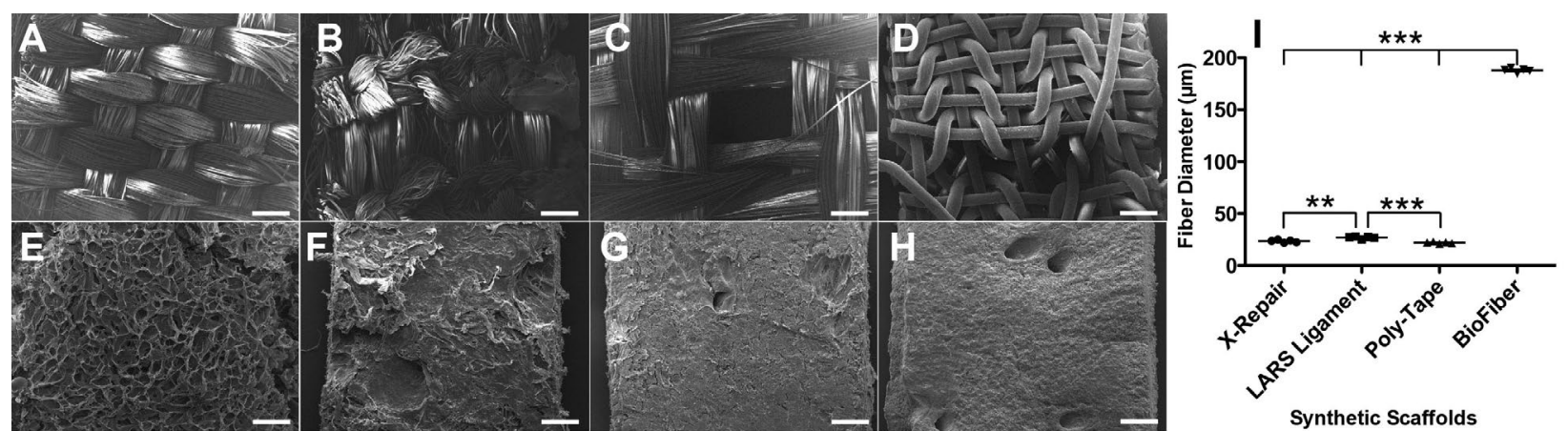

Fig 1. Scaffold morphology. ESEM micrographs showing the appearance of the scaffolds. X-Repair (A), LARS Ligament (B), Poly-Tape (C), BioFiber (D), BioFiber-CM (E), GraftJacket (F), Permacol (G), Conexa $(\mathbf{H})$. $50 \times$ magnification. Scale bar $=600 \mu \mathrm{m}$. The diameter of individual fibres of the synthetic scaffolds was measured from the ESEM images (I). Bar represents mean.
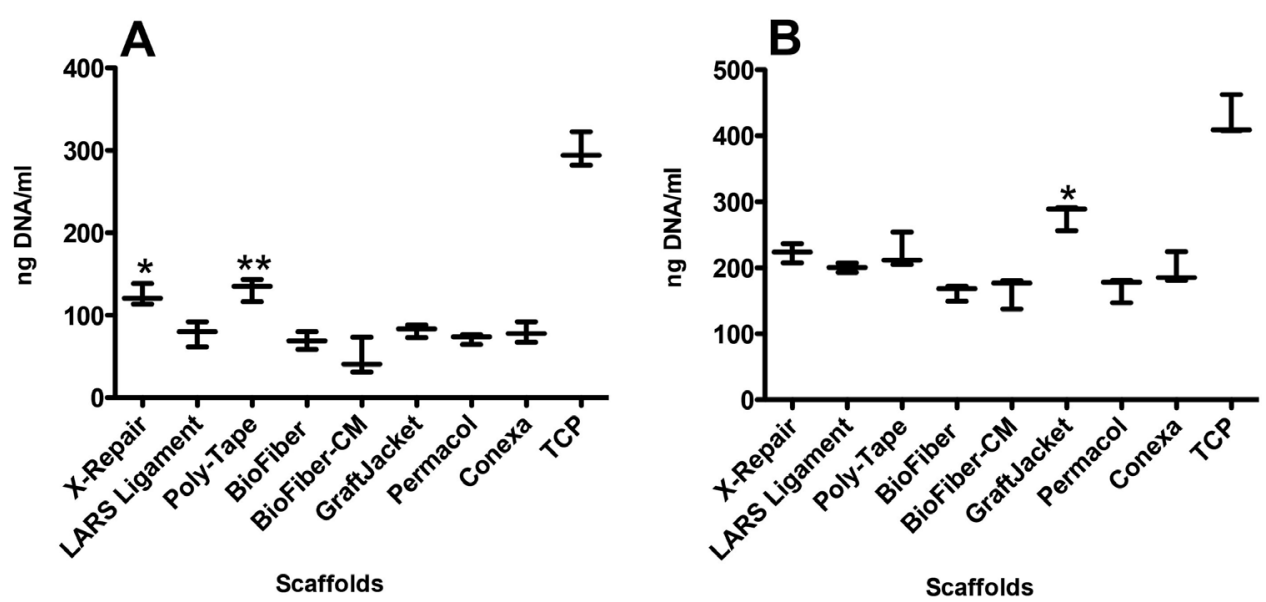

Fig 2. Amount of DNA extracted from cells on scaffolds on day 1 and day 13. DNA was quantified using PicoGreen and this was used to approximate the number of cells that attached to each scaffold on day 1 (A) and day 13 (B). On day 1 , X-Repair had significantly more DNA than every other scaffold $(p \leq 0.05)$ except Poly-Tape (A). This is shown in (A) as one asterisk above X-Repair. On day 1, Poly-Tape had significantly more DNA than every other scaffold $(p \leq 0.01)$ except X-Repair $(\mathbf{A})$. This is shown in $(\mathbf{A})$ as two asterisks above Poly-Tape. On day 1, there was no statistical difference in DNA quantity between X-Repair and Poly-Tape (A). On day 13, GraftJacket had more DNA than every other scaffold $(p \leq 0.05)(\mathbf{B})$. This is shown in $(\mathbf{B})$ as one asterisk above GraftJacket. Graphs represent median with minimum and maximum $(n=3)$.

scaffolds, then there is no significant difference between the scaffolds that are different. For example, in Fig. 2A, $\mathrm{X}$-Repair and Poly-Tape are significantly different from every other scaffold. However, there is no significant difference between X-Repair and Poly-Tape.

\section{Results}

\section{Scaffold morphology}

Synthetic scaffolds demonstrated different weave patterns (Fig. 1A-D) and fibre diameters (Fig. 1I). The average fibre diameter of BioFiber was larger than the three other synthetic scaffolds $(p \leq 0.001)$ (Fig. 1I). The average fibre diameter of LARS Ligament was larger than X-Repair and Poly-Tape ( $p \leq 0.01$ and $p \leq 0.001$ respectively) while the average fibre diameters of X-Repair and Poly-Tape were equivalent (Fig. 1I). X-Repair (Fig. 1A) and Poly-Tape (Fig. 1C) had plain weave patterns, with straight and perpendicular bundles of fibres. LARS ligament (Fig. 1B) had an array of straight fibres with the addition of twisted fibre bundles. BioFiber (Fig. 1D) had a lattice of parallel fibres, interwoven with curved fibres. BioFiber (Fig. 1D) displayed thick fibres with high porosity, whereas BioFiber-CM (its bovine-collagen coated equivalent Fig. 1E) appeared flat and dense. GraftJacket (Fig. 1F), the human dermal scaffold, appeared rougher than the two porcine dermal scaffolds of Permacol (Fig. 1G) and Conexa (Fig. 1H).

\section{Cell attachment and proliferation}

After $1 \mathrm{~d}$, more cells attached to X-Repair $(p \leq 0.05)$ and Poly-Tape ( $p \leq 0.01)$ than any other scaffold as measured by dsDNA content (Fig. 2A). All other scaffolds demonstrated similar amounts of dsDNA.

AlamarBlue was used to study the change in cell number (cell proliferation) on the scaffolds over $13 \mathrm{~d}$. After $1 \mathrm{~d}$, cell number $/ \mathrm{cm}^{2}$ was higher on X-Repair $(p \leq 0.05)$ and Poly-Tape $(p \leq 0.05)$ than any other scaffold (Fig. 3A). After $13 \mathrm{~d}$, cell number/ $\mathrm{cm}^{2}$ was higher on GraftJacket $(p \leq 0.05)$ than any other scaffold (Fig. 3A), which was confirmed measuring the total dsDNA (Fig. 2B). No statistical differences in cell number $/ \mathrm{cm}^{2}$ were observed between any other scaffolds (Fig. 3A). 

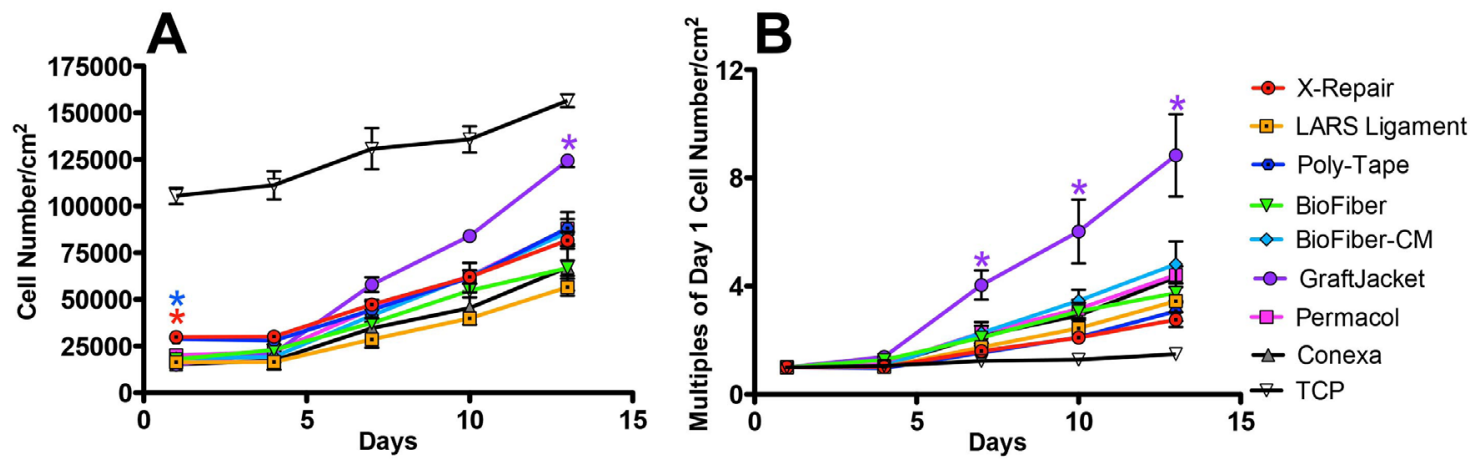

Fig 3. Proliferation of cells on scaffolds over $13 \mathrm{~d}$. The absolute proliferation of cells on scaffolds was measured every $3 \mathrm{~d}$ for $13 \mathrm{~d}$ using AlamarBlue (A). On day 1, more cells were attached to X-Repair than every other scaffold $(p \leq 0.05)$ except Poly-Tape (A). This is shown in (A) as one red asterisk above day 1. On day 1, more cells attached to Poly-Tape than every other scaffold $(p \leq 0.05)$ except X-Repair $(\mathbf{A})$. This is shown in $(\mathbf{A})$ as one blue asterisk above day 1. On day 1, there was no statistical difference in cell number between X-Repair and Poly-Tape (A). On day 13, more cells attached to GraftJaket than every other scaffold $(p \leq 0.05)(\mathbf{A})$. This is shown in (A) as one purple asterisk above day 13. Measurements were also standardised to day 1 to determine the relative proliferation of the cells that did attach $(\mathbf{B})$. Of the cells that did attach, cells were significantly more proliferative on GraftJacket on day $7(p \leq 0.05)$, day $10(p \leq 0.05)$, and day $13(p \leq 0.05)$ when compared to every other scaffold (B). These are shown in (B) as one purple asterisk above days 7, 10 and 13, respectively. Graphs represent median with minimum and maximum $(n=3)$.
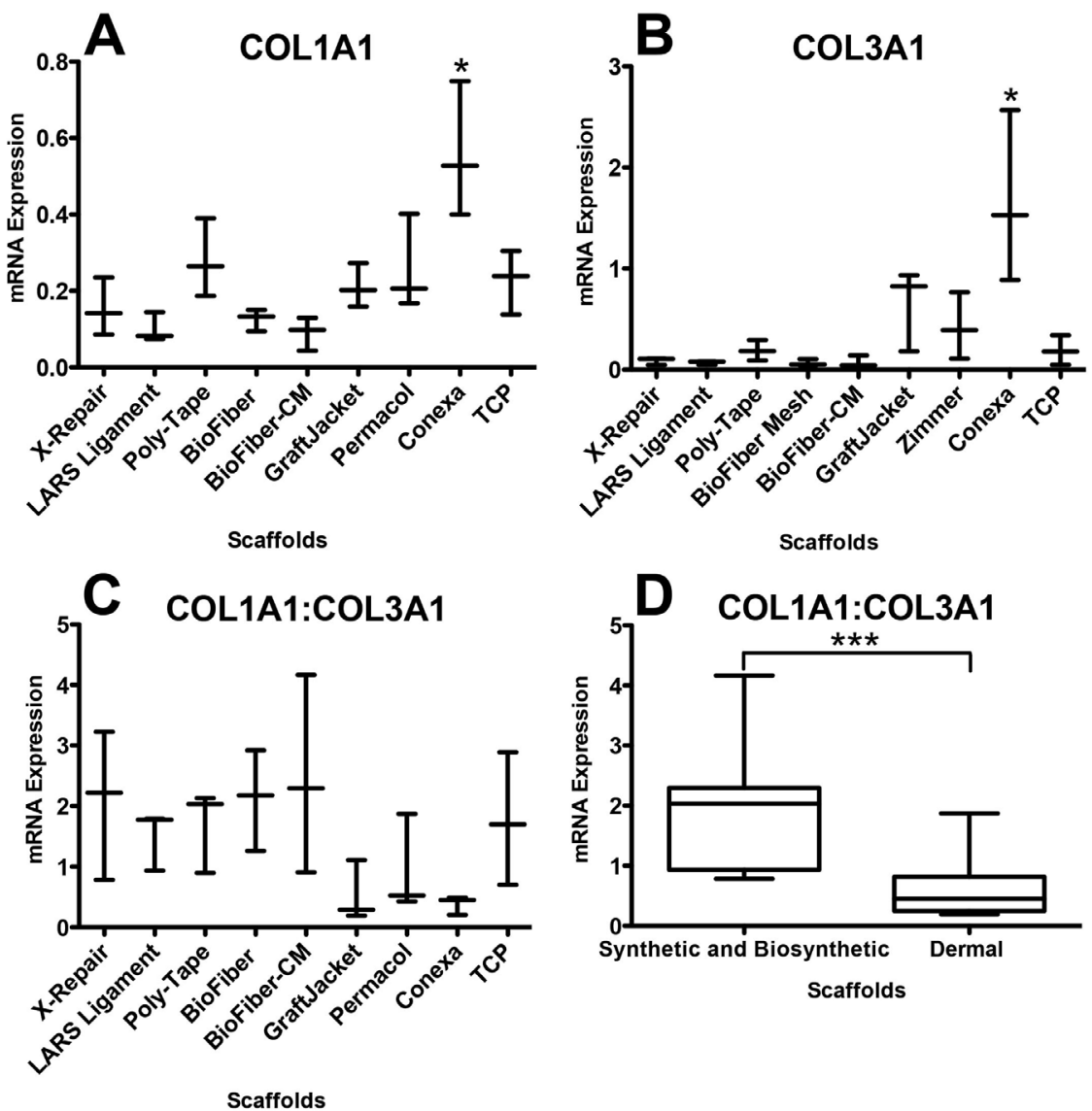

Fig 4. Day 13 mRNA expression. After 13 d, mRNA expression of COL1A1 (A) and COL3A1 (B) was calculated relative to GAPDH. After $13 \mathrm{~d}, C O L 1 A 1$ expression was greater on Conexa than every other scaffold $(p \leq 0.05)(\mathbf{A})$. This is shown in (A) as one asterisk above Conexa. After $13 \mathrm{~d}, C O L 3 A 1$ was greater on Conexa than every other scaffold $(p \leq 0.05)(\mathbf{B})$. This is shown in (B) as one asterisk above Conexa. The ratio of COL1A1:COL3A1 mRNA after $13 \mathrm{~d}$ was also calculated $(\mathbf{C})$. An unpaired $t$-test was performed to compare the ratio of COL1A1:COL3A1 on synthetic and biosynthetic scaffolds, against dermal scaffolds (D). The ratio of COL1A1:COL3A1 was higher on synthetic and biosynthetic scaffolds, compared to dermal scaffolds $(p=0.0009)$ (D). This is shown in (D) as three asterisks above line comparing the two groups. Graphs represent median with minimum and maximum $(n=3)$. 


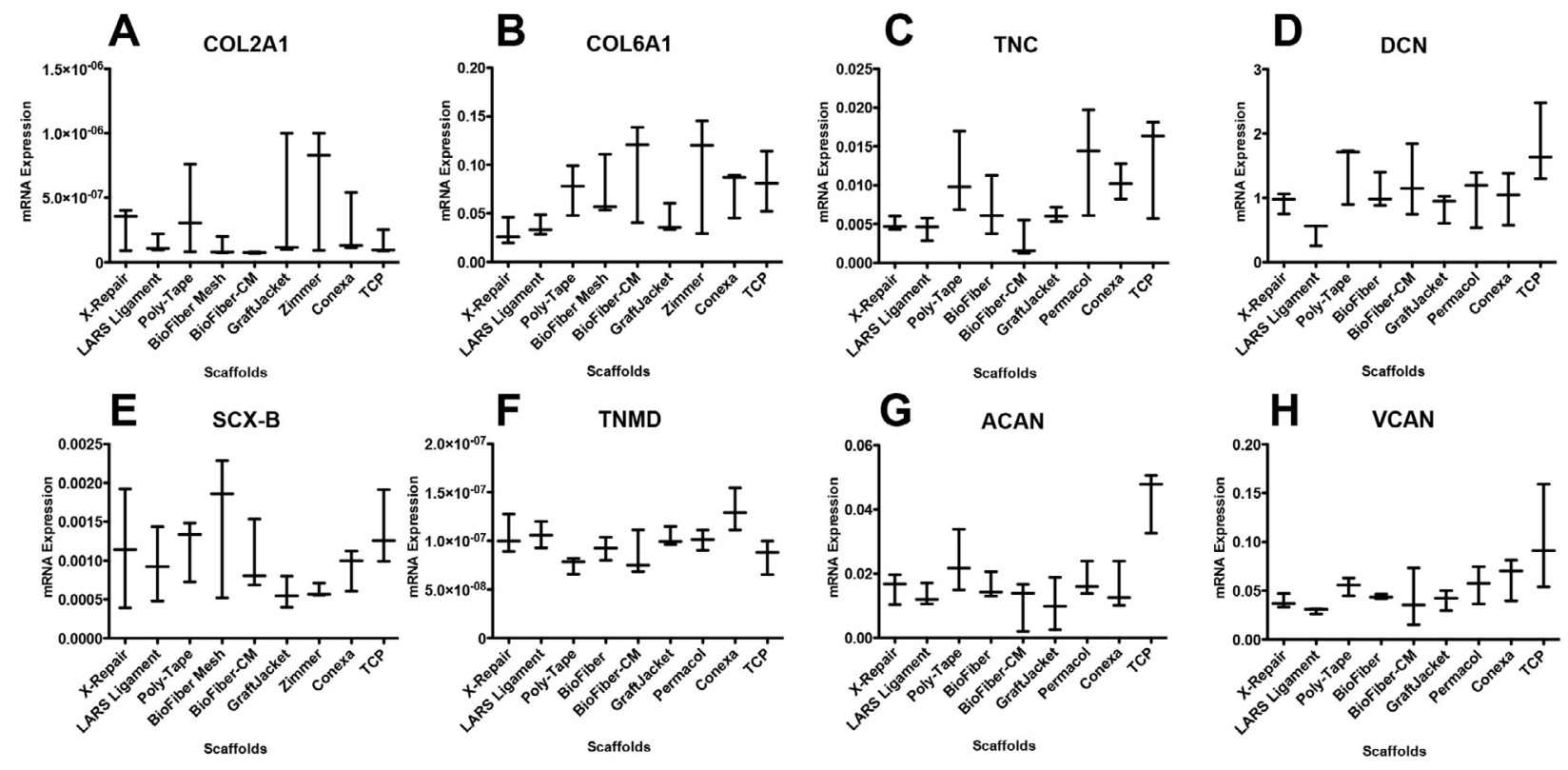

Fig 5. Day 13 mRNA expression. After $13 \mathrm{~d}$, mRNA expression was calculated relative to GAPDH. COL2A1 (A), COL6A1 (B), TNC (C), DCN (D), SCX-B (E), TNMD (F), $A C A N(\mathbf{G}), V C A N(\mathbf{H})$. None of the scaffolds demonstrated significant differences for gene expression. Graphs represent median with minimum and maximum $(n=3)$.

Cell number per $\mathrm{cm}^{2}$ for each scaffold was standardised to day 1 values to determine the relative proliferation of cells that attached to each scaffold (Fig. 3B). Cells that initially attached proliferated more on GraftJacket than any other scaffold after $7 \mathrm{~d}(p \leq 0.05), 10 \mathrm{~d}(p \leq 0.05)$ and $13 \mathrm{~d}$ $(p \leq 0.05)$ (Fig. 3B). There were no statistically significant differences at any other time points.

\section{Gene expression}

After $13 \mathrm{~d}$, mRNA expression of collagen types I and III were determined by RT-qPCR of cells on scaffolds. Expression of collagen types I (COL1A1) and III (COL3A1) were higher in cells on Conexa than all other scaffolds $(p \leq 0.05)$ (Fig. $4 \mathbf{A}$ and $4 \mathbf{B})$. The ratio of COL1A1:COL3A1 mRNA expression was higher on synthetic and biosynthetic scaffolds (X-Repair, LARS Ligament, Poly-Tape, BioFiber, BioFiber-CM) than dermal scaffolds (GraftJacket, Permacol, Conexa) $(p=0.0009)$ (Fig. 4D). After $13 \mathrm{~d}$, expression of COL2A1, COL6A1, $T N C, D C N, S C X-B, T N M D, V C A N$ and $A C A N$ were also assessed. No significant differences were seen between the scaffolds tested (Fig. 5)

\section{Cell morphology}

On day 13, cells on X-Repair, LARS ligament, and PolyTape looked like healthy native tenocytes, with extended lamellipodia aligning along the lengths of the scaffold fibres (Fig. 6B, D, F respectively). On day 13, cells on BioFiber aligned along fibres, but also exhibited filopodia that were transverse to fibre direction (Fig. 6H). In contrast, on day 13 cells on BioFiber-CM, GraftJacket, Permacol, and Conexa exhibited filopodia that extended in different directions (Fig. 6J, L, N, P respectively). After $13 \mathrm{~d}$, cells on GraftJacket were smooth (Fig. 6L), while cells on Permacol (Fig. 6N) and Conexa (Fig. 6P) appeared dendritic and punctate.

\section{Discussion}

Rotator cuff tears are a prevalent pathology, and surgical repair is not always effective. Numerous scaffolds have been developed to augment the surgical repair and reduce re-tearing. However, little is known about how the degenerative tissue, and in particular the native cells, interact with these scaffolds. In this study, we compared the response of patient-derived rotator cuff tenocytes to 8 commercially available scaffolds. We show that X-Repair and Poly-Tape promoted the greatest cell attachment after $1 \mathrm{~d}$ and that GraftJacket promoted the greatest level of cell proliferation over $13 \mathrm{~d}$. Expression of COL1A1 and $C O L 3 A 1$ was significantly upregulated in cells grown on Conexa after $13 \mathrm{~d}$. In addition, the ratio of COL1A1 to COL3A1 mRNA was lower on all dermal scaffolds tested compared to synthetic and biosynthetic scaffolds.

For the implanted scaffold to be incorporated into the body, native tissue cells must attach to its surface and then migrate into the material. For adherent cells such as tenocytes, attachment is necessary for cell proliferation (Singhvi et al., 1994) and survival (Folkman and Moscona, 1978; Ben-Ze'ev et al., 1980). After 1 d, cell attachment was greatest on X-Repair and Poly-Tape, both synthetic scaffolds with dense arrays of aligned fibres with diameters of $\sim 22-23 \mu \mathrm{m}$. This result was unexpected as cells usually adhere more to hydrophilic surfaces and less to hydrophobic surfaces (Wei et al., 2007; Webb et al., 1998; Schakenraad et al., 1986; Altankov et al., 1996). X-Repair and Poly-Tape are composed of poly-L-lactic acid and polyethylene terapthelate respectively, both of which are hydrophobic (Van Wachem et al., 1985; Hsieh and Cram, 1998). In contrast, GraftJacket, Permacol, and Conexa are derived from mammalian dermis which is hydrophilic (Gniadecka et al., 1998). One plausible explanation is that synthetic micro-fibre scaffolds provide a large effective 
Day 1


Day 13

B

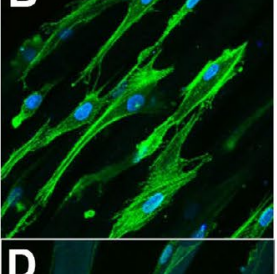

D
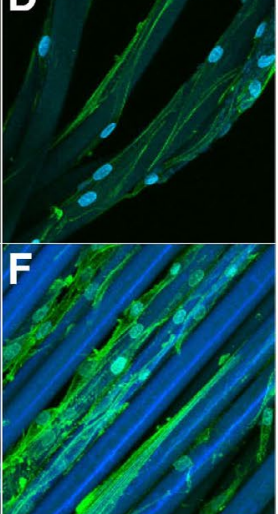

H

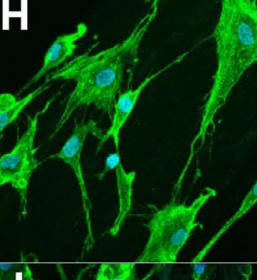

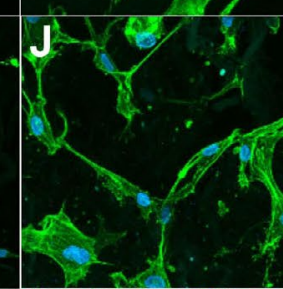

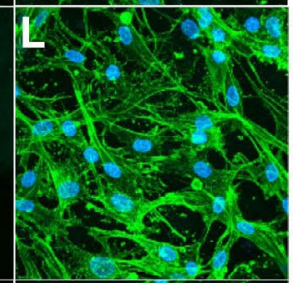

N
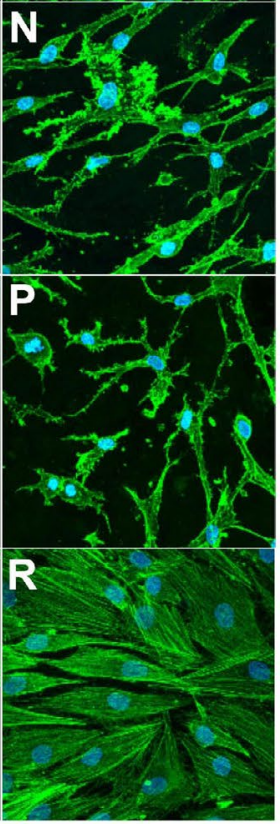

surface area, allowing cells to attach above and within the scaffold. Previous studies have demonstrated increased cell attachment to biomaterials with increasing surface area (O'Brien et al., 2005; Mo et al., 2004; Murphy et al., 2010). However, other material properties, such as elastic modulus, wettability, and roughness may also influence cell attachment.

Over 13 d, cell proliferation was greatest on GraftJacket, a minimally processed human dermis composed of collagen types I, III, IV and VII, elastin, proteoglycans and native growth factors, such as Fibroblast Growth Factor (FGF) (Coons and Barber, 2006). Many forms of FGF exist and their influence on cell proliferation has been well documented (Boilly et al., 2000; Piotrowicz et al., 1999). However, the mechanism behind the increase in cell proliferation on GraftJacket reported here remains to be investigated. While our study suggests that human cells proliferate more on human dermis than porcine dermis, it is unclear whether this response is due to difference in tissue source (human vs. porcine) or processing techniques used during manufacturing. GraftJacket is derived from human dermis that is not sterilised or cross-linked (Shea et al., 2010) and is classified as human tissue for transplantation (Longo et al., 2010) under the FDA Code of Federal regulations Title 21 Part 1270 (Ricchetti et al., 2012). In contrast, Permacol is derived from porcine dermis and undergoes extensive mechanical and enzymatic processing (Longo et al., 2010; Kimuli et al., 2004) and is chemically cross-linked (Derwin et al., 2006). Conexa is also derived from porcine dermis and is processed to minimise immunological reactions, but is not cross-linked (Ricchetti et al., 2012). The proprietary nature of these processing techniques makes it difficult to determine their precise impact on the ECM and the subsequent cellular response. While several studies have investigated the effect of these processing techniques (Reing et al., 2010; Brown et al., 2011) on cellular response, only a small number of techniques were studied and therefore future investigations are required. It is noteworthy that the topography and structure of the scaffolds may have influenced the rate of cell proliferation. Previous studies suggest that cell proliferation varies between two-dimensional and threedimensional scaffolds (Bott et al., 2010; Cukierman et al., 2001). Our presented data support this, with clear differences in cell proliferation on the three-dimensional scaffolds compared to the cells on two-dimensional TCP.

Despite increased cell attachment on X-Repair and Poly-Tape, there was no corresponding significant increase in cell proliferation over $13 \mathrm{~d}$. This result is supported by previous studies, which have shown that surface area is correlated with increased cell attachment (O'Brien et al., 2005; Mo et al., 2004; Murphy et al., 2010) but not

Fig 6. Fluorescent images of cell morphology on scaffolds. Cell morphology was assessed on days 1 and 13 using confocal microscopy. Cell cytoskeleton was stained with phalloidin (green) and nucleus was counterstained using DAPI (blue). Magnification $40 \times$. Scale bar $=50 \mu \mathrm{m}$. X-Repair (A, B), LARS Ligament (C, D), Poly-Tape (E, F), BioFiber (G, H), BioFiber-CM $(\mathbf{I}, \mathbf{J})$, GraftJacket $(\mathbf{K}, \mathbf{L})$, Permacol $(\mathbf{M}, \mathbf{N})$, Conexa $(\mathbf{O}, \mathbf{P})$, TCP $(\mathbf{Q}, \mathbf{R})$. 
necessarily with increased cellular proliferation (Murphy et al., 2010).

After $13 \mathrm{~d}$, expression of COL1A1 and COL3A1 were significantly upregulated in cells on Conexa. Cellular production of new extracellular matrix proteins is critical for healing and neo-tissue formation. Collagen type I is the fundamental component of tendon (Amiel et al., 1984; von der Mark, 1981) and affords the tendon with high strength (Jozsa et al., 1984). In contrast, collagen III is associated with tendon healing and fibrosis (Leask and Abraham, 2004; Gurtner et al., 2008) and is mechanically inferior to collagen I (Maffulli et al., 2000). While no individual scaffold demonstrated a statistically different ratio of COL1A1:COL3A1, there was a clear difference between dermal scaffolds (GraftJacket, Permacol, Conexa) in comparison to biosynthetic (BioFiber-CM) and synthetic scaffolds (X-Repair, LARS Ligament, Poly-Tape, BioFiber). When stratified into separate groups, dermal scaffolds demonstrated a lower COL1A1:COL3A1 ratio than biosynthetic and synthetic scaffolds. Lower ratios of collagen I to collagen III results in thinner collagen fibres (Dale et al., 1996) and reduced tissue stability (Birk and Mayne, 1997; Klinge et al., 2000). Decreased ratios of collagen I to collagen III expression is seen during skin scarring (Klinge et al., 2000) and it is interesting to consider the possibility that residual physical and chemical cues in the dermal scaffolds promote this behaviour.

Our results contrast with a previous in vitro study by Shea et al. (2010) that found significantly increased collagen I mRNA expression on GraftJacket and Conexa, while demonstrating increased collagen III mRNA expression on GraftJacket, Conexa and Permacol. These differences may be due to different sampling time points or the use of different cell types; we utilised cells from rotator cuff tear patients, while Shea et al. used tenocytes derived from healthy tendons that were discarded during orthopaedic procedures (Shea et al., 2010). Indeed, underlying changes in the tissue precede rotator cuff tears (Kannus and Jozsa, 1991). Therefore, the phenotype of cells within diseased tissues is likely different. The differential response between healthy and patient-derived cells may have important implications when evaluating the cellular response to biomaterials in vitro.

We observed dramatic differences in cell morphology on different scaffolds. After $1 \mathrm{~d}$, cells on all scaffolds appeared rounded in comparison to tissue culture plastic (TCP), where cells were flattened. In contrast, after $13 \mathrm{~d}$ cell morphology differed markedly between the scaffold types tested. Cells on synthetic scaffolds aligned by following the orientation of the fibres, while cells on biosynthetic or dermal scaffolds were more isotropic and extended in numerous different directions, similar to TCP. We observed distinct differences in cell morphology between the dermal scaffolds; cells on human dermal scaffolds appeared smooth and interconnected, whereas cells on porcine dermal scaffolds appeared dendritic and punctate. Previous work suggests that the morphology of fibroblast-like cells transition from dendritic to smooth when the substrate they are on is sufficiently stiff (Tamariz and Grinnell, 2002).
The results from this study suggest that the addition of collagen to BioFiber to make BioFiber-CM did not significantly affect cell adhesion, proliferation or gene expression in vitro. Conflicting results exist in the literature, with some studies reporting improved cellular response with collagen-coated biomaterials (Nagai et al., 2002; Röhlecke et al., 2001) and some studies reporting no differences (Becker et al., 2002; van den Dolder et al., 2003). In tendon, tenocytes are organised into rows of connected cells within a pericellular matrix (Thakkar et al., 2014) and their behaviour is greatly influence by their connectivity with other cells (Schulze-Tanzil et al., 2004). Examination of cell morphology after $13 \mathrm{~d}$ revealed a sparse distribution of cells which did not form the connected networks like those seen on BioFiber (Fig. 5H). This is rather surprising, and merits further investigation, and especially a comparison to an in vivo system. It may simply be that the deposited collagen did not form a pattern conductive to the formation of aligned cell arrays, or there may be another variable in the process of coating which may have affected the response of the cells to the surface.

There is increasing evidence that inflammation, and the cells that mediate it, are important in the pathogenesis and healing of tendon tears (Sharma and Maffulli, 2005; Millar et al., 2010; Dakin et al., 2015). Following surgical implantation, scaffolds will come into contact with a range of inflammatory cells, including monocytes, neutrophils, and macrophages (Anderson et al., 2008; Anderson, 2001). Several studies have shown significant differences in the response of these inflammatory cells to materials used for hernia repair (Orenstein et al., 2010; Grotenhuis et al., 2013) and dental implants (Refai et al., 2004; Stanford, 2010). However, the response of inflammatory cells to scaffold materials used for rotator cuff repair has not been thoroughly studied and warrants further investigation.

The main strengths of our work include comparing a large number of scaffolds and utilising patient-derived cells from diseased tissue. There are several limitations of our work, which must be considered. Firstly, we used cells from a small number of patients $(n=3)$ and the response of cells from other patients may differ. Secondly, we only studied one cell type, and it is likely that the interaction between native tenocytes and other cell types, such as macrophages, determine the patient's response to a scaffold. Finally, we performed the study in static tissue culture and were therefore unable to replicate the complex mechanical loading profile that the scaffolds would experience in vivo. These factors must be considered and as such, the relevance of our in vitro findings to clinical performance is limited.

\section{Conclusion}

Overall, this study suggests that synthetic scaffolds with large effective surface areas promoted increased cell adhesion, minimally processed human dermis promote cellular proliferation, and non-cross-linked porcine dermis promotes the expression of collagen types I and III in patient-derived tenocytes. By revealing potential advantages and disadvantages of each scaffold type, our 
data may help determine which scaffold is most appropriate for augmenting surgical rotator cuff repairs.

Future work in the field should use cells from unhealthy tissue to better understand the native biological mechanisms involved in rotator cuff repair and how scaffolds can be used to enhance these processes. Also, well-designed randomised control clinical trials comparing different scaffolds will help surgeons determine the most appropriate type of scaffold for clinical use. The influence that industrial processing techniques and collagen coating have on the cellular response to biomaterials warrants further investigation.

\section{Acknowledgements}

This study was funded by a grant from Tornier, Inc. The authors would like to thank Synthasome for kindly providing their materials. The NIHR Oxford Biomedical Research Unit supported Richard Smith, Professor Andrew Carr, Dr Stephanie Dakin, Dr Sarah Snelling, and Dr Osnat Hakimi. Dr Stephanie Dakin and Dr Sarah Snelling were also funded by Arthritis Research UK grants 20506 and 20087 respectively.

\section{References}

Ahmed SA, Gogal RM Jr, Walsh JE (1994) A new rapid and simple non-radioactive assay to monitor and determine the proliferation of lymphocytes: an alternative to $[3 \mathrm{H}]$ thymidine incorporation assay. J Immunol Methods 170: 211-224.

Altankov G, Grinnell F, Groth T (1996) Studies on the biocompatibility of materials: Fibroblast reorganization of substratum-bound fibronectin on surfaces varying in wettability. J Biomed Mater Res 30: 385-391.

Amiel D, Frank C, Harwood F, Fronek J, Akeson W (1984) Tendons and ligaments: a morphological and biochemical comparison. J Orthop Res 1: 257-265.

Anderson JM (2001) Biological responses to materials. Annu Rev Mater Res 31: 81-110.

Anderson JM, Rodriguez A, Chang DT (2008) Foreign body reaction to biomaterials. Semin Immunol 20: 86-100.

Aurora A, McCarron J, Iannotti JP, Derwin K (2007) Commercially available extracellular matrix materials for rotator cuff repairs: state of the art and future trends. J Shoulder Elbow Surg 16: S171-S178.

Badylak SF (2007) The extracellular matrix as a biologic scaffold material. Biomaterials 28: 3587-3593.

Becker D, Geissler U, Hempel U, Bierbaum S, Scharnweber D, Worch H, Wenzel KW (2002) Proliferation and differentiation of rat calvarial osteoblasts on type I collagen-coated titanium alloy. J Biomed Mater Res 59: 516-527.

Ben-Ze'ev A, Farmer SR, Penman S (1980) Protein synthesis requires cell-surface contact while nuclear events respond to cell shape in anchorage-dependent fibroblasts. Cell 21: 365-372.

Birk DE, Mayne R (1997) Localization of collagen types I, III and V during tendon development. Changes in collagen types I and III are correlated with changes in fibril diameter. Eur J Cell Biol 72: 352-361.

Bissell MJ, Aggeler J (1987) Dynamic reciprocity: how do extracellular matrix and hormones direct gene expression? Prog Clin Biol Res 249: 251-262.

Bissell MJ, Barcellos-Hoff MH (1987) The influence of extracellular matrix on gene expression: is structure the message? J. Cell Sci Suppl1987: 327-343.

Boilly B, Vercoutter-Edouart AS, Hondermarck H, Nurcombe V, Le Bourhis X (2000) FGF signals for cell proliferation and migration through different pathways. Cytokine Growth Factor Rev 11: 295-302.

Bott K, Upton Z, Schrobback K, Ehrbar M, Hubbell JA, Lutol MP, Rizzi SC (2010) The effect of matrix characteristics on fibroblast proliferation in $3 \mathrm{D}$ gels. Biomaterials 31: 8454-8464.

Brown BN, Freund JM, Han L, Rubin JP, Reing JE, Jeffries EM, Wolf MT, Tottey S, Barnes CA, Ratner BD, Badylak SF (2011) Comparison of three methods for the derivation of a biologic scaffold composed of adipose tissue extracellular matrix. Tissue Eng Part C Methods 17: 411-421.

Chaudhury S, Gwilym SE, Moser J, Carr AJ (2010) Surgical options for patients with shoulder pain. Nat Rev Rheumatol 6: 217-226.

Chen J, Xu J, Wang A, Zheng M (2009) Scaffolds for tendon and ligament repair: review of the efficacy of commercial products. Expert Rev Med Devices 6: 61-73.

Cook JL, Fox DB, Kuroki K, Jayo M, De Deyne PG (2008) In vitro and in vivo comparison of five biomaterials used for orthopedic soft tissue augmentation. Am J Vet Res 69: $148-156$.

Coons DA, Barber FA (2006) Tendon graft substitutes - rotator cuff patches. Sports Med Arthrosc 14: 185-190.

Cornwell KG, Landsman A, James KS (2009) Extracellular matrix biomaterials for soft tissue repair. Clin Podiatr Med Surg 26: 507-523.

Cukierman E, Pankov R, Stevens DR, Yamada KM (2001) Taking cell-matrix adhesions to the third dimension. Science 294: 1708-1712.

Dakin SG, Martinez FO, Yapp C, Wells G, Oppermann U, Dean BJ, Smith RD, Wheway K, Watkins B, Roche L, Carr AJ (2015) Inflammation activation and resolution in human tendon disease. Sci Transl Med 7: doi: 10.1126/ scitranslmed.aac4269.

Dale PD, Sherratt JA, Maini PK (1996) A mathematical model for collagen fibre formation during foetal and adult dermal wound healing. Proc iol Sci 263: 653-660.

Dejardin LM, Arnoczky SP, Ewers BJ, Haut RC, Clarke RB (2001) Tissue-engineered rotator cuff tendon using porcine small intestine submucosa Histologic and mechanical evaluation in dogs. Am J Sports Med 29: 175184.

DePalma AF, Callery G, Bennett GA (1949) Variational anatomy and degenerative lesions of the shoulder joint. Instr Course Lect 6: 255-281.

Derwin KA, Badylak SF, Steinmann SP, Iannotti JP (2010) Extracellular matrix scaffold devices for rotator cuff repair. J Shoulder Elbow Surg 19: 467-476.

Derwin KA, Baker AR, Spragg RK, Leigh DR, Iannotti JP (2006) Commercial extracellular matrix scaffolds for 
rotator cuff tendon repair. Biomechanical, biochemical, and celluar properties. J Bone Joint Surg Am 88: 2665-2672.

Derwin KA, Codsi MJ, Milks RA, Baker AR, McCarron JA, Iannotti JP (2009) Rotator cuff repair augmentation in a canine model with use of a woven poly-L-lactide device. J Bone Joint Surg Am 91: 1159-1171.

Folkman J, Moscona A (1978) Role of cell shape in growth control. Nature 1: 345-349.

Galatz LM, Ball CM, Teefey SA, Middleton WD, Yamaguchi K (2004) The outcome and repair integrity of completely arthroscopically repaired large and massive rotator cuff tears. J Bone Joint Surg Am 86: 219-224.

Gerber C, Fuchs B, Hodler J (2000) The results of repair of massive tears of the rotator cuff. J Bone Joint Surg Am 82: $505-515$.

Gniadecka M, Nielsen OF, Wessel S, Heidenheim M, Christensen DH, Wulf HC (1998) Water and protein structure in photoaged and chronically aged skin. J Invest Dermatol 111: 1129-1132.

Gong J, Sagiv O, Cai H, Tsang SH, Del Priore LV (2008) Effects of extracellular matrix and neighboring cells on induction of human embryonic stem cells into retinal or retinal pigment epithelial progenitors. Exp Eye Res 86: 957-965.

Grotenhuis N, Bayon Y, Lange JF, Van Osch GJ, Bastiaansen-Jenniskens YM (2013) A culture model to analyze the acute biomaterial-dependent reaction of human primary macrophages. Biochem Biophys Res Commun 433: 115-120.

Gurtner GC, Werner S, Barrandon Y, Longaker MT (2008) Wound repair and regeneration. Nature 453: 314321.

Hsieh YL, Cram LA (1998) Enzymatic hydrolysis to improve wetting and absorbency of polyester fabrics. Text Res J 68: 311-319.

Iannotti JP, Codsi MJ, Kwon YW, Derwin K, Ciccone J, Brems JJ (2006) Porcine small intestine submucosa augmentation of surgical repair of chronic two-tendon rotator cuff tears. A randomized, controlled trial. J Bone Joint Surg Am 88: 1238-1244.

Jozsa L, Balint BJ, Reffy A, Demel Z (1984) Fine structural alterations of collagen fibers in degenerative tendinopathy. Arch Orthop Trauma Surg 103: 47-51.

Judge A, Murphy RJ, Maxwell R, Arden NK, Carr AJ (2014) Temporal trends and geographical variation in the use of subacromial decompression and rotator cuff repair of the shoulder in England. Bone Joint J 96: 70-74.

Kannus P, Jozsa L (1991) Histopathological changes preceding spontaneous rupture of a tendon. A controlled study of 891 patients. J Bone Joint Surg Am 73: 1507-1525.

Kimuli M, Eardley I, Southgate J (2004) In vitro assessment of decellularized porcine dermis as a matrix for urinary tract reconstruction. BJU Int 94: 859-866.

Klinge U, Si ZY, Zheng H, Schumpelick V, Bhardwaj RS, Klosterhalfen B (2000) Abnormal collagen I to III distribution in the skin of patients with incisional hernia. Eur Surg Res 32: 43-48.

Lafosse L, Brozska R, Toussaint B, Gobezie R (2007) The outcome and structural integrity of arthroscopic rotator cuff repair with use of the double-row suture anchor technique. J Bone Joint Surg Am 89: 1533-1541.
Leask A, Abraham DJ (2004) TGF- $\beta$ signaling and the fibrotic response. FASEB J 18: 816-827.

Ling SC, Chen CF, Wan RX (1990) A study on the vascular supply of the supraspinatus tendon. Surg Radiol Anat 12: 161-165.

Longo UG, Lamberti A, Maffulli N, Denaro V (2010) Tendon augmentation grafts: a systematic review. Br Med Bull 94: 165-188.

Maffulli N, Ewen SWB, Waterston SW, Reaper J, Barrass V (2000) Tenocytes from ruptured and tendinopathic Achilles tendons produce greater quantities of type III collagen than tenocytes from normal Achilles tendons. An in vitro model of human tendon healing. Am J Sports Med 28: 499-505.

Malcarney HL, Bonar F, Murrell GA (2005) Early inflammatory reaction after rotator cuff repair with a porcine small intestine submucosal implant: a report of 4 cases. Am J Sports Med 33: 907-911.

Marx RG, Koulouvaris P, Chu SK, Levy BA (2009) Indications for surgery in clinical outcome studies of rotator cuff repair. Clin Orthop Relat Res 467: 450-456.

McCarron JA, Milks RA, Chen X, Iannotti JP, Derwin KA (2010) Improved time-zero biomechanical properties using poly-L-lactic acid graft augmentation in a cadaveric rotator cuff repair model. J Shoulder Elbow Surg 19: 688696.

Millar NL, Hueber AJ, Reilly JH, Xu Y, Fazzi UG, Murrell GA, McInnes IB (2010) Inflammation is present in early human tendinopathy. Am J Sports Med 38: 2085 2091.

Millar NL, Reilly JH, Kerr SC, Campbell AL, Little KJ, Leach WJ, Rooney BP, Murrell GA, McInnes IB (2012) Hypoxia: a critical regulator of early human tendinopathy. Ann Rheum Dis 71: 302-310.

Mo XM, Xu CY, Kotaki M, Ramakrishna S (2004) Electrospun P(LLA-CL) nanofiber: a biomimetic extracellular matrix for smooth muscle cell and endothelial cell proliferation. Biomaterials 25: 1883-1890.

Murphy CM, Haugh MG, O'Brien FJ (2010) The effect of mean pore size on cell attachment, proliferation and migration in collagen-glycosaminoglycan scaffolds for bone tissue engineering. Biomaterials 31: 461-466.

Nagai M, Hayakawa T, Fukatsu A, Yamamoto M, Fukumoto M, Nagahama F, Mishima H, Yoshinari M, Nemoto K, Kato T (2002) In vitro study of collagen coating of titanium implants for initial cell attachment. Dent Mater J 21: 250-260.

Neer CS (1983) Impingement lesions. Clin Orthop Relat Res 173: 70-77.

O’Brien FJ, Harley BA, Yannas I V, Gibson LJ (2005) The effect of pore size on cell adhesion in collagen-GAG scaffolds. Biomaterials 26: 433-441.

Orenstein SB, Qiao Y, Klueh U, Kreutzer DL, Novitsky YW (2010) Activation of human mononuclear cells by porcine biologic meshes in vitro. Hernia 14: 401-407.

Phipatanakul WP, Petersen SA (2009) Porcine small intestine submucosa xenograft augmentation in repair of massive rotator cuff tears. Am J Orthop (Belle Mead NJ) 38: $572-575$.

Piotrowicz RS, Maher PA, Levin EG (1999) Dual activities of 22-24 kDA basic fibroblast growth factor: 
inhibition of migration and stimulation of proliferation. J Cell Physiol 178: 144-153.

Post M, Silver R, Singh M (1983) Rotator cuff tear: Diagnosis and treatment. Clin Orthop Relat Res 173: 78-91.

Refai AK, Textor M, Brunette DM, Waterfield JD (2004) Effect of titanium surface topography on macrophage activation and secretion of proinflammatory cytokines and chemokines. J Biomed Mater Res A 70: 194-205.

Reing JE, Brown BN, Daly KA, Freund JM, Gilbert TW, Hsiong SX, Huber A, Kullas KE, Tottey S, Wolf MT, Badylak SF (2010) The effects of processing methods upon mechanical and biologic properties of porcine dermal extracellular matrix scaffolds. Biomaterials 31: 8626-8633.

Reing JE, Zhang L, Myers-Irvin J, Cordero KE, Freytes DO, Heber-Katz E, Bedelbaeva K, McIntosh D, Dewilde A, Braunhut SJ (2009) Degradation products of extracellular matrix affect cell migration and proliferation. Tissue Eng Part A 15: 605-614.

Ricchetti ET, Aurora A, Iannotti JP, Derwin KA (2012) Scaffold devices for rotator cuff repair. J Shoulder Elbow Surg 21: 251-265.

Röhlecke C, Witt M, Kasper M, Schulze E, Wolf C, Hofer A, Funk RW (2001) Synergistic effect of titanium alloy and collagen type I on cell adhesion, proliferation and differentiation of osteoblast-like cells. Cells Tissues Organs 168: 178-187.

Schakenraad JM, Busscher HJ, Wildevuur CR, Arends J (1986) The influence of substratum surface free energy on growth and spreading of human fibroblasts in the presence and absence of serum proteins. J Biomed Mater Res 20: 773-784.

Schmittgen TD, Livak KJ (2008) Analyzing real-time PCR data by the comparative CT method. Nat Protoc 3: 1101-1108.

Schulze-Tanzil G, Mobasheri A, Clegg PD, Sendzik J, John T, Shakibaei M (2004) Cultivation of human tenocytes in high-density culture. Histochem. Cell Biol 122: 219-228.

Sclamberg SG, Tibone JE, Itamura JM, Kasraeian S (2004) Six-month magnetic resonance imaging follow-up of large and massive rotator cuff repairs reinforced with porcine small intestinal submucosa. J Shoulder Elb Surg 13: $538-541$.

Sharma P, Maffulli N (2005) Tendon injury and tendinopathy: healing and repair. J Bone Joint Surg Am 87: 187-202.

Shea KP, McCarthy MB, Ledgard F, Arciero C, Chowaniec D, Mazzocca AD (2010) Human tendon cell response to 7 commercially available extracellular matrix materials: an in vitro study. Arthroscopy 26: 1181-1188.

Singhvi R, Kumar A, Lopez GP, Stephanopoulos GN, Wang DI, Whitesides GM, Ingber DE (1994) Engineering cell shape and function. Science 264: 696-698.

Stanford CM (2010) Surface modification of biomedical and dental implants and the processes of inflammation, wound healing and bone formation. Int J Mol Sci 11: 354369.

Sugaya H, Maeda K, Matsuki K, Moriishi J (2007) Repair integrity and functional outcome after arthroscopic double-row rotator cuff repair. A prospective outcome study. J Bone Joint Surg 89: 953-960.
Tamariz E, Grinnell F (2002) Modulation of fibroblast morphology and adhesion during collagen matrix remodeling. Mol Biol Cell 13: 3915-3929.

Thakkar D, Grant TM, Hakimi O, Carr AJ (2014) Distribution and expression of type VI collagen and elastic fibers in human rotator cuff tendon tears. Connect Tissue Res 55: 397-402.

Urwin M, Symmons D, Allison T, Brammah T, Busby H, Roxby M, Simmons A, Williams G (1998) Estimating the burden of musculoskeletal disorders in the community: the comparative prevalence of symptoms at different anatomical sites, and the relation to social deprivation. Ann Rheum Dis 57: 649-655.

Van Wachem PB, Beugeling T, Feijen J, Bantjes A, Detmers JP, Van Aken WG (1985) Interaction of cultured human endothelial cells with polymeric surfaces of different wettabilities. Biomaterials 6: 403-408.

Van den Dolder J, Bancroft GN, Sikavitsas VI, Spauwen PH, Mikos AG, Jansen JA (2003) Effect of fibronectin-and collagen I-coated titanium fiber mesh on proliferation and differentiation of osteogenic cells. Tissue Eng 9: 505-515.

Vitale MA, Vitale MG, Zivin JG, Braman JP, Bigliani LU, Flatow EL (2007) Rotator cuff repair: an analysis of utility scores and cost-effectiveness. J Shoulder Elbow Surg 16: 181-187.

Von der Mark K (1981) Localization of collagen types in tissues. Int Rev Connect Tissue Res 9: 265-324.

Voytik-Harbin SL, Brightman AO, Waisner B, Lamar CH, Badylak SF (1998) Application and evaluation of the AlamarBlue assay for cell growth and survival of fibroblasts. In Vitro Cell Biol Anim 34: 239-246.

Voytik-Harbin SL, Brightman AO, Kraine MR, Waisner B, Badylak SF (1997) Identification of extractable growth factors from small intestinal submucosa. J Cell Biochem 67: 478-491.

Webb K, Hlady V, Tresco PA (1998) Relative importance of surface wettability and charged functional groups on NIH 3T3 fibroblast attachment, spreading, and cytoskeletal organization. J Biomed Mater Res 41: 422430.

Wei J, Yoshinari M, Takemoto S, Hattori M, Kawada E, Liu B, Oda Y (2007) Adhesion of mouse fibroblasts on hexamethyldisiloxane surfaces with wide range of wettability. J Biomed Mater Res B Appl Biomater 81: 6675.

Yamamoto A, Takagishi K, Osawa T, Yanagawa T, Nakajima D, Shitara H, Kobayashi T (2010) Prevalence and risk factors of a rotator cuff tear in the general population. J Shoulder Elbow Surg 19: 116-120.

Yao L, Bestwick CS, Bestwick LA, Maffulli N, Aspden RM (2006) Phenotypic drift in human tenocyte culture. Tissue Eng 12: 1843-1849.

Zalavras CG, Gardocki R, Huang E, Stevanovic M, Hedman T, Tibone J (2006) Reconstruction of large rotator cuff tendon defects with porcine small intestinal submucosa in an animal model. J Shoulder Elb Surg 15: 224-231.

Zantop T, Gilbert TW, Yoder MC, Badylak SF (2006) Extracellular matrix scaffolds are repopulated by bone marrow-derived cells in a mouse model of achilles tendon reconstruction. J Orthop Res 24: 1299-1309. 
Zhang X, Bogdanowicz D, Erisken C, Lee NM, Lu $\mathrm{HH}$ (2012) Biomimetic scaffold design for functional and integrative tendon repair. J Shoulder Elbow Surg 21: 266277.

\section{Discussion with Reviewers}

Matthew Fisher: The severity of rotator cuff injury can vary wildly. Do the authors think the best scaffold is dependent on the severity of injury?

Authors: We agree that there is a broad spectrum of rotator cuff pathology. Previous work in our group has revealed distinct differences in patient groups when stratified by attributes such as tear size, levels of inflammation, and pain. Therefore, it is likely that the type of scaffold that is most appropriate for each patient will vary depending upon a range of different factors. Currently, scaffolds are reserved for patients with large or massive rotator cuff tears. This is because these patients are at much greater risk of re-tearing following a standard surgical repair and would therefore benefit from a scaffold-augmented repair. This is why we only used cells from patients with large or massive rotator cuff tears i.e. tear size $\geq 3 \mathrm{~cm}$.

Matthew Fisher: Upon in vivo implantation, will the injured rotator cuff cells be the ones to repopulate the graft? What about other cell types?

Authors: Immediately following implantation, many inflammatory cells will invade the repair site. We believe that the way that these inflammatory cells interact with the implanted scaffold, and subsequently influence the healing response, are important aspects to understand. As such, this is the topic of an on-going research project. In terms of cell types repopulating the graft, most of the inflammatory cells are transient. This is because the healing tendon transitions from the acute inflammatory stage to the proliferative stage of repair after 1-7 d. We know that many other cell types have been detected around a healing tendon such as synoviocytes, chondrocytes, and osteocytes, but the vast majority of cells in tendon tissue are resident tenocytes. Tenocytes are the main cell population responsible for maintaining and repairing tendon tissue. As such, we believe that tenocytes will be the main cell type that will repopulate the graft. While the identity of the healing cells in tendon is subject of much debate, we believe that tendon-derived proliferative cells play an important role in tendon healing. These cells are derived directly from human supraspinatus tendon tissue biopsies and are the cells that will directly interact with the scaffold following surgical implantation in vivo.

Gundula Gesine Schlulze-Tanzil: Only cells attached to the scaffold were accounted for. Were the detached cells also calculated separately to get an impression of the whole cell number?
Authors: AlamarBlue assays were performed on the old tissue culture plates after scaffolds were transferred out of them, to explore whether cells were detaching at a different rate from different scaffolds. However, after day 1, very few cells detached from any of the scaffolds and no differences between scaffolds were detected.

Gundula Gesine Schlulze-Tanzil: The AlamarBlue assay usually assesses only metabolic activity, please explain how the cell proliferation was calculated from the extinction shift produced by metabolised AlamarBlue. Authors: AlamarBlue is an assay that measures the metabolic activity of cells. In order to calculate cell number from this, we had to assume that metabolism of the cells from each patient were approximately the same on the different scaffolds. We created a calibration curve for each patient using different cell concentrations. From this, we were able to convert each AlamarBlue fluorescence reading to an approximate cell number. We used the PicoGreen assay to validate this and confirm that changes were in fact due to more cells and not due to a change in cell metabolic activity on a particular material. Our PicoGreen results support our AlamarBlue results.

Gundula Gesine Schlulze-Tanzil: Cell adherence was measured in the study, but how about the cell penetration into the scaffold? It is important for the formation of new functional tissue.

Authors: We tried to analyse this, but with the porous synthetic scaffolds, cells were present on every side of the scaffold following cell-seeding. Therefore, it was impossible to determine whether the cells migrated there or whether they just adhered there following cell seeding. Because we were unable to make a fair comparison across all 8 scaffolds, we decided not to include these data.

Gundula Gesine Schlulze-Tanzil: Was a degradation of the biomaterials by cells observed?

Authors: In the preliminary study, SEM analysis of cells on scaffolds was performed and after $28 \mathrm{~d}$ in culture, no significant degradation of any of the scaffolds was observed. However, this was a crude evaluation, and it can be assumed that some degradation has occurred either through hydrolysis or enzymatic degradation from cell-secreted enzymes. We previously analysed collagen protein expression using an ELISA for collagen type 1, but decided to omit the results because we were unable to account for the enzymatic degradation of the collagenbased biological scaffolds.

Editor's Note: Scientific Editor in charge of the paper: Juerg Gasser. 